\title{
Microwave Limb Sounder observations of biomass-burning products from the Australian bush fires of February 2009
}

\author{
H. C. Pumphrey ${ }^{1}$, M. L. Santee ${ }^{2}$, N. J. Livesey ${ }^{2}$, M. J. Schwartz ${ }^{2}$, and W. G. Read ${ }^{2}$ \\ ${ }^{1}$ School of GeoSciences, The University of Edinburgh, Edinburgh, UK \\ ${ }^{2}$ NASA Jet Propulsion Laboratory, Pasadena, CA, USA \\ Received: 14 January 2011 - Published in Atmos. Chem. Phys. Discuss.: 23 February 2011 \\ Revised: 31 May 2011 - Accepted: 22 June 2011 - Published: 1 July 2011
}

\begin{abstract}
The large bush fires which occurred in southeast Australia in February 2009 were unusually destructive. However, they were also unusual in the amounts of various combustion products which were injected directly into the stratosphere. We report the observations by the Microwave Limb Sounder (MLS) instrument on the Aura satellite of some of these combustion products. The highest quality observations are of $\mathrm{CO}$; these clearly show a large region of enhanced mixing ratios to the north of New Zealand which remains in that region for about ten days before drifting westwards and finally dissipating over the Atlantic about a month after the fire. The region of enhanced $\mathrm{CO}$ ascends from the tropopause to $46 \mathrm{hPa}$ during this period. Back trajectories run from the points where MLS observes enhanced CO pass close to the site of the fire. The MLS observations of $\mathrm{CH}_{3} \mathrm{CN}$ and $\mathrm{HCN}$ resemble those of $\mathrm{CO}$ except for their poorer vertical resolution and more limited vertical range. An apparent enhancement in $\mathrm{ClO}$ is also observed by MLS, but detailed analysis of the measured radiances reveals this feature to be a signature of $\mathrm{CH}_{3} \mathrm{OH}$, which is not currently retrieved by the MLS data processing system. The fires of February 2009 are the only event of this type and magnitude in the 7-yr MLS record.
\end{abstract}

\section{Introduction}

Biomass burning releases a wide variety of chemicals into the atmosphere (Andreae and Merlet, 2001). The phenomenon is prevalent enough to permit many of these chemical species to be observed by satellite remote sensing (Rinsland et al.,

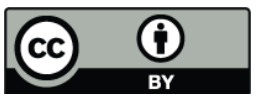

Correspondence to: H. C. Pumphrey (h.c.pumphrey@ed.ac.uk)
2007; Coheur et al., 2007, 2009; Turquety et al., 2009). While much of this pollution is emitted into the boundary layer, a vigorous fire may release sufficient heat to cause a convective event, thereby releasing the pollutants at a greater altitude (Fromm et al., 2010).

On 7 February 2009, the state of Victoria suffered the most damaging series of bush fires on record for Australia. 173 lives were lost and the damage has been estimated by a Royal Commission (Teague et al., 2010) to be of the order of AUS\$ 4.4 billion. The event has become known as Black Saturday. One of the many extreme aspects of this event was the altitude reached by the plume of combustion products. These products include both smoke particles and gases. In this paper we report on the gaseous combustion products as observed by the Microwave Limb Sounder (MLS) instrument on NASA's Aura platform.

Aura (Schoeberl et al., 2006) was launched in July 2004, and the MLS instrument (Waters et al., 2006) has operated with little interruption from August 2004 to date. MLS measures the mixing ratios of a number of chemical species, including several biomass burning products. It was known prior to the MLS launch that injections of such gases into the lower stratosphere do occur (see e.g. Fromm and Servranckx, 2003; Fromm et al., 2010), and can be observed by a microwave limb-sounding instrument (Livesey et al., 2004). It was part of the MLS science plan to observe any such events that might occur during the mission.

\section{The observations}

MLS consists of a $1.6 \mathrm{~m}$ parabolic dish antenna feeding heterodyne radiometers operating at 118, 190, 240 and $640 \mathrm{GHz}$. A separate small antenna feeds another radiometer

Published by Copernicus Publications on behalf of the European Geosciences Union. 
operating at $2.5 \mathrm{THz}$. The output of the radiometers is analysed by banks of filters. The antenna looks forward from the Aura platform, in the plane of the orbit, and is scanned across the Earth's limb 240 times per orbit. As the orbit is inclined at $98^{\circ}$ to the equator, the instrument observes a latitude range from $82^{\circ} \mathrm{S}$ to $82^{\circ} \mathrm{N}$ every day. The observations are of thermal emission from the atmosphere and can therefore be made day and night. The orbit is sun-synchronous, so the observations are always made at the same two local times for a given latitude. The radiances reported by the filter banks are used as input to a software package (Livesey et al., 2006) which estimates profiles of temperature, and of the mixing ratios of the target chemical species. Most MLS estimated profiles are reported on pressure levels spaced at 6 levels per pressure decade, a spacing of approximately $2.7 \mathrm{~km}$. An exception is $\mathrm{H}_{2} \mathrm{O}$, which is reported at 12 levels per pressure decade for part of its vertical range. All mixing ratios in this paper are produced by version 2.2 (V2.2) of this software package. The precisions and accuracies of these data are summarised in a data quality document (Livesey et al., 2007).

Among the suite of MLS V2.2 measurements are three biomass-burning products: carbon monoxide (CO) (Livesey et al., 2008; Pumphrey et al., 2007), Hydrogen Cyanide (HCN) (Pumphrey et al., 2006, 2008) and acetonitrile (methyl cyanide, $\mathrm{CH}_{3} \mathrm{CN}$ ). Of these, the $\mathrm{CO}$ data are the most reliable and best-validated. The $\mathrm{CO}$ data are of good quality at the $100 \mathrm{hPa}$ and $147 \mathrm{hPa}$ levels and at all higher altitudes in the middle atmosphere. At the $215 \mathrm{hPa}$ level the data are usable with care: a positive bias of about $100 \%$ must be accounted for (Livesey et al., 2008). The lowest level at which retrieval is attempted is $316 \mathrm{hPa}$; the data at this level are very highly correlated with the data at $215 \mathrm{hPa}$.

The $\mathrm{HCN}$ and $\mathrm{CH}_{3} \mathrm{CN}$ data have not been extensively validated (Livesey et al., 2007). The HCN data are known to have biases of around $100 \%$ in the lower stratosphere $(100 \mathrm{hPa}-10 \mathrm{hPa})$ when compared with earlier in-situ measurements. There are large regions (mostly at higher latitudes) where the retrieved mixing ratios are persistently negative. The random error on a single profile is around $0.025 \mathrm{ppbv}$ (about $10 \%$ ) at $31 \mathrm{hPa}$ and higher altitudes, worsening rapidly to $0.08 \mathrm{ppbv}$ (about $40 \%$ ) at $100 \mathrm{hPa}$.

Two separate $\mathrm{CH}_{3} \mathrm{CN}$ products are produced: one from the $190 \mathrm{GHz}$ region and one from the $640 \mathrm{GHz}$ region; there are systematic differences between the products and both have large biases in the lower stratosphere when compared to earlier measurements (e.g. Schneider et al., 1997; Singh et al., 2003). Both products must therefore be used with some caution. Although the $190 \mathrm{GHz} \mathrm{CH} \mathrm{CH}_{3} \mathrm{CN}$ is the standard product in V2.2, subsequent analysis suggests that the $640 \mathrm{GHz}$ $\mathrm{CH}_{3} \mathrm{CN}$ provides better sensitivity. The random errors in the $640 \mathrm{GHz} \mathrm{CH}_{3} \mathrm{CN}$ product are about $0.03 \mathrm{ppbv}$ at $31 \mathrm{hPa}$, $0.05 \mathrm{ppbv}$ at $100 \mathrm{hPa}$ and $0.15 \mathrm{ppmv}$ at $147 \mathrm{hPa}$. The bias in the lower stratosphere is positive and is very approximately

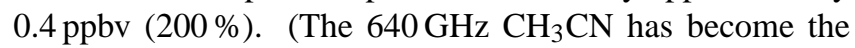
standard $\mathrm{CH}_{3} \mathrm{CN}$ product in version 3 of the MLS data; that

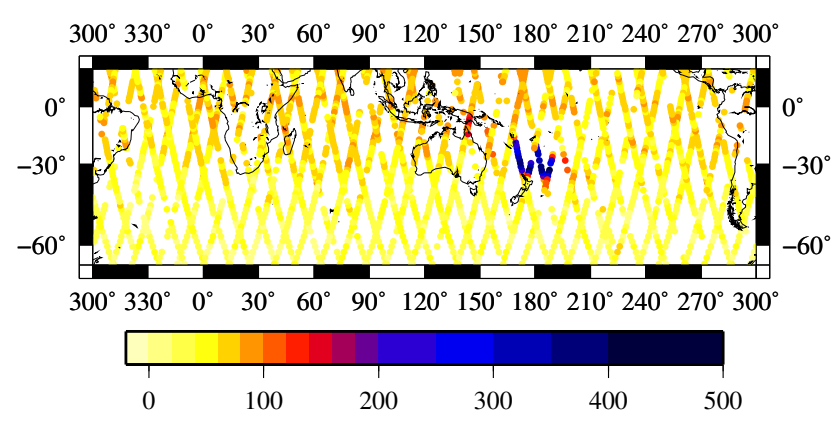

Fig. 1. MLS CO volume mixing ratio (in ppbv) at $100 \mathrm{hPa}$ on 12 and 13 February 2009. Each dot represents a single MLS data point. Both descending and ascending orbits are shown. Successive ascending (or descending) orbits are separated by $24^{\circ}$ of longitude. The ascending orbit tracks for a given day are displaced by approximately $12^{\circ}$ of longitude from those of the previous day. Values plotted as purple and blue are much larger than those usually seen at this altitude. Negative values can occur in places where the mixing ratio is small compared to the measurement error.

version was released after this paper was written.) As the $\mathrm{CO}$ is the most reliable of these three MLS measurements of biomass-burning products, we used it to obtain an overview of the Black Saturday event.

\subsection{Mapping the plume}

Figure 1 shows the MLS CO mixing ratio at $100 \mathrm{hPa}$ on 12 and 13 February 2009. The orbits from 13 February lie in between the orbits from 12 February.

As we will show later, the region of large values to the north of New Zealand is a direct result of the Black Saturday fires. Figure 1 is typical of the two weeks following the fire. To summarise the development of the fire-affected airmass, we began by identifying which of the MLS measurements are clearly part of that airmass. We did this by finding the mean value and standard deviation for all measurements in a given latitude band and at a given pressure level. We then defined a point as affected if its mixing ratio was more than 4.2 standard deviations above the mean. (The value of 4.2 is somewhat arbitrary but in practice tends to detect most of the interesting events while rejecting almost all of the background points.) An iterative approach is used to ensure that the mean and standard deviation are calculated from the unaffected points; there are few enough affected points that this calculation converges very quickly. Figure 2 shows the locations of the affected points in four consecutive 6-day periods at six of the standard MLS pressure levels in the upper troposphere and lower stratosphere.

The points are clustered to the north of New Zealand and to the east of Australia for the first six days. In the next six days the plume of pollutants becomes elongated and drawn out towards the southeast. Over the following twelve days most of 

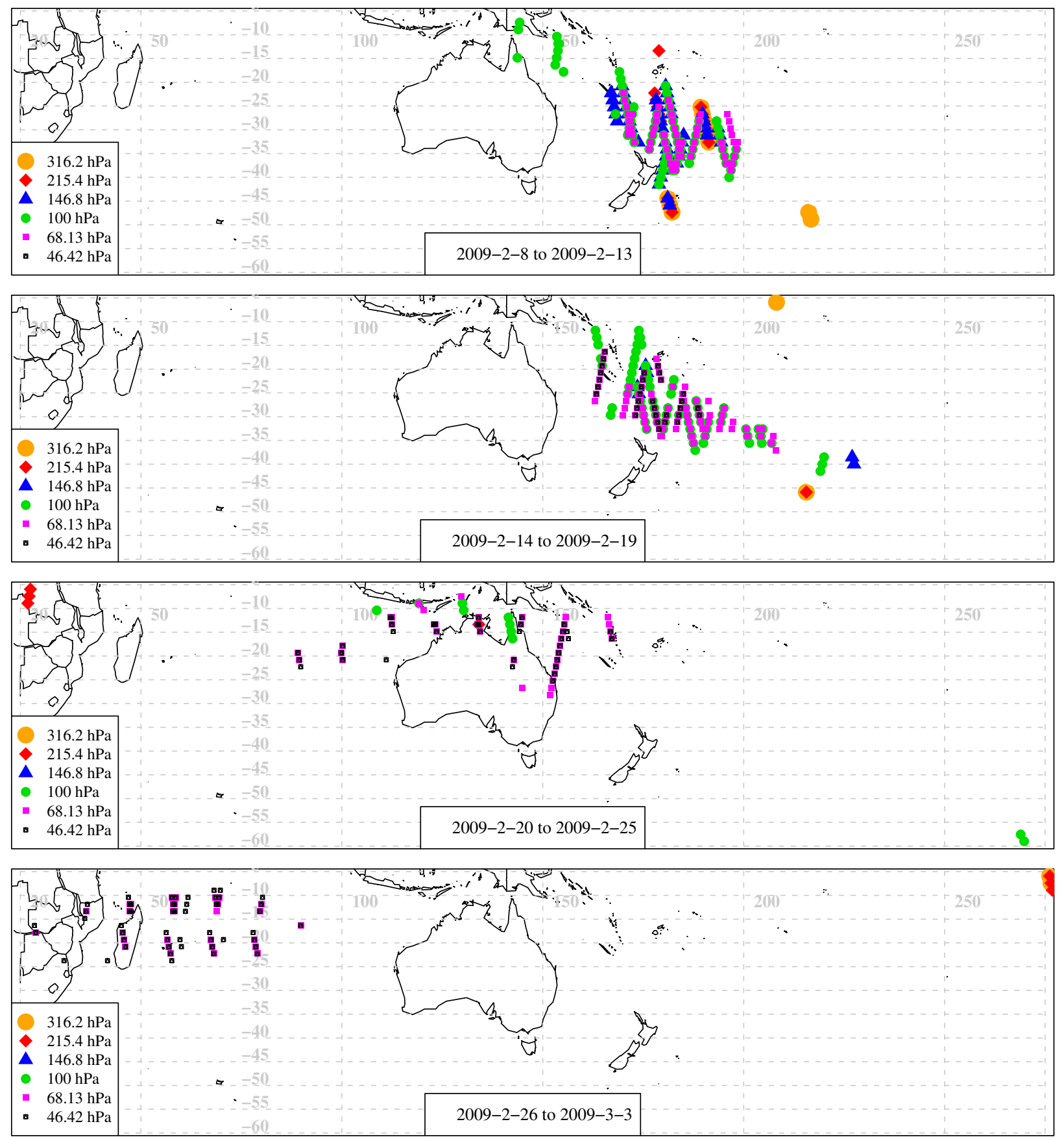

Fig. 2. Locations of MLS measurements where the CO values are anomalously high as defined in the text. The four maps show four successive 6-day periods beginning on 8 February, one day after the Black Saturday fire. (Dates are shown at the bottom of each panel in the form Year-month-day.) Apart from a few instances at the higher pressures, these points all appear to be part of the same event.

the plume moves northwestwards and then westwards, passing across the Indian ocean towards Africa. A smaller component at $100 \mathrm{hPa}$ moves towards the southeast; this is just visible in the third panel of Fig. 2.

To further summarise the history of the polluted airmass, we show in Fig. 3 the number of points identified as unusual at each MLS pressure level, as a function of time.
Figure 4 shows how many standard deviations above the mean the points identified as unusual in Fig. 3 were.

It is clear from Figs. 3-4 that the event is observable from day 39 of 2009 ( 8 February), the day after the fires, until day 70 of 2009 (11 March). It is also clear from Figs. 2-4 that the $46 \mathrm{hPa}$ level is not affected by the plume until the 8 th day of the event, and remains affected after the other levels have 


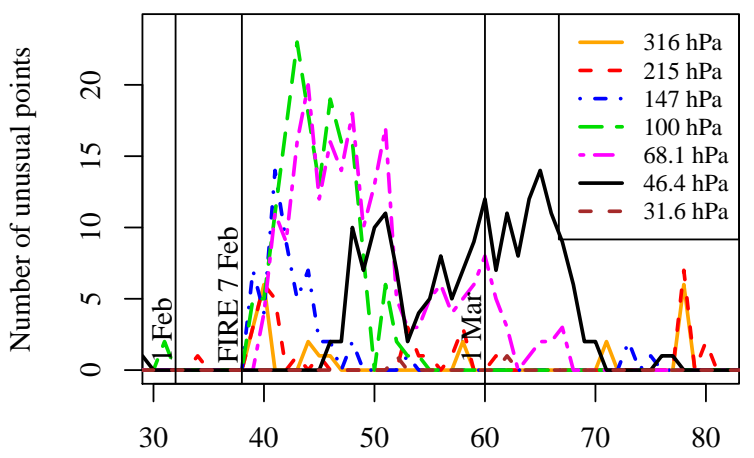

Time / Day of 2009

Fig. 3. Number of points for each day for which the $\mathrm{CO}$ mixing ratio was identified as unusual (as defined in the text) in the $5^{\circ} \mathrm{S}-60^{\circ} \mathrm{S}$ latitude range.

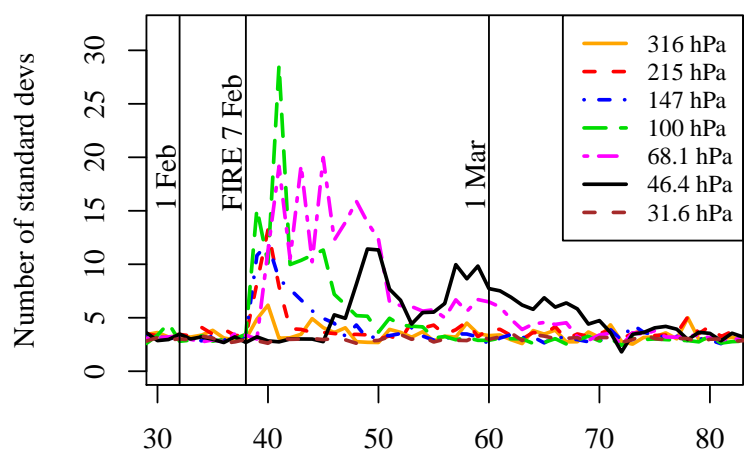

Time / Day of 2009

Fig. 4. Mean number of standard deviations above the mean $\mathrm{CO}$ mixing ratio for the points identified as unusual in Fig. 3.

returned to their background values. This suggests that the polluted region in the stratosphere is ascending as it moves. At the $215 \mathrm{hPa}$ and $147 \mathrm{hPa}$ levels the enhancement lasts for only a few days. This is probably because these levels are in the upper troposphere or lowermost stratosphere; these regions have more rapid mixing than does the stratosphere at $100 \mathrm{hPa}$ and higher altitudes.

\subsection{Enhancements of other species in the polluted airmass}

\subsubsection{Retrieved mixing ratios}

The large enhancement in $\mathrm{CO}$ is the most obvious difference between the polluted airmass described above and the surrounding air. We now consider whether any of the other species observed by MLS are enhanced or depleted within the polluted airmass. An MLS measurement location was marked as being polluted by using the $\mathrm{CO}$ mixing ratio

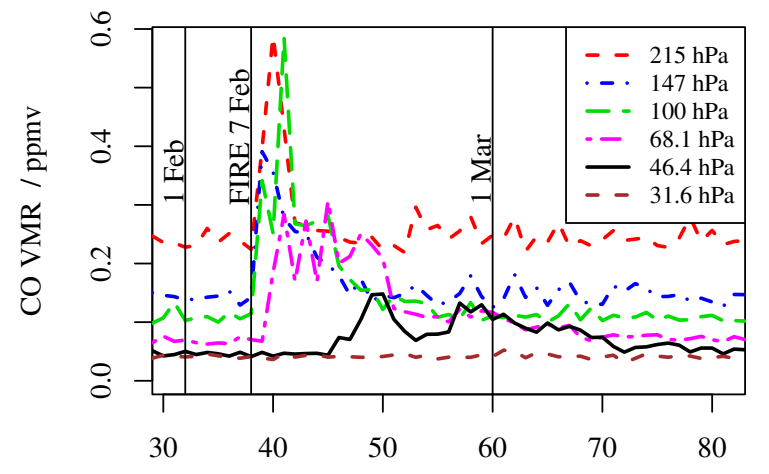

Time / Day of 2009

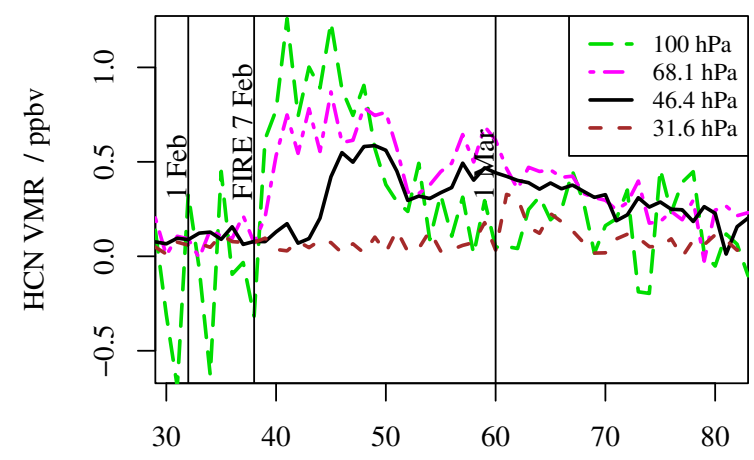

Time / Day of 2009

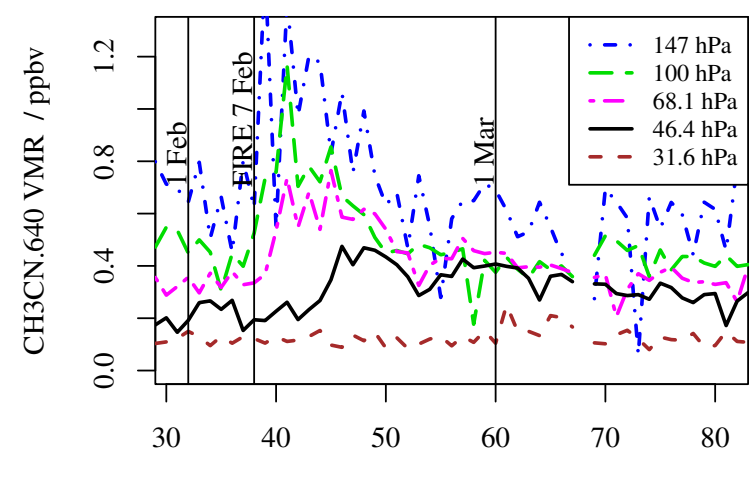

Time / Day of 2009

Fig. 5. Time series of the mixing ratio of MLS CO, HCN and $\mathrm{CH}_{3} \mathrm{CN}$ within the polluted airmass. The $\mathrm{CH}_{3} \mathrm{CN}$ shown is that derived from the $640 \mathrm{GHz}$ measurements.

as described in Sect. 2.1, and the daily mean mixing ratio of various species for the marked locations was calculated. Where there are no affected points we show an average from whichever three points happened to have the largest $\mathrm{CO}$ mixing ratio. Although these points could lie anywhere between $5^{\circ} \mathrm{S}$ and $60^{\circ} \mathrm{S}$, they all have rather similar $\mathrm{CO}$ values. Some results are shown in Figs. 5 and 6; $\mathrm{CO}$ itself is plotted in Fig. 5 to facilitate direct comparison. 


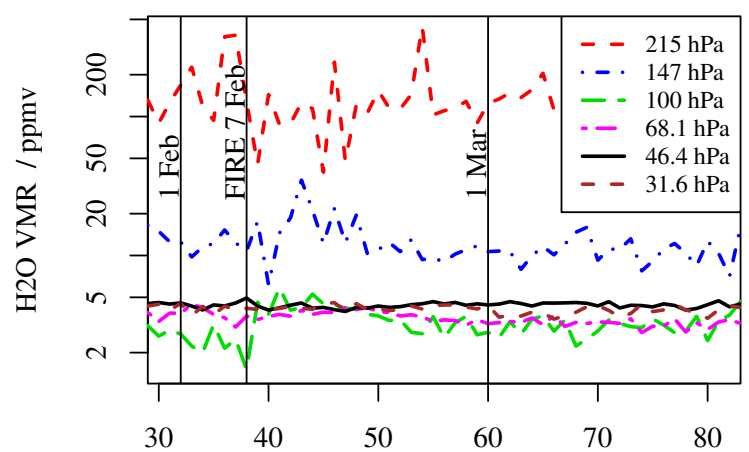

Time / Day of 2009

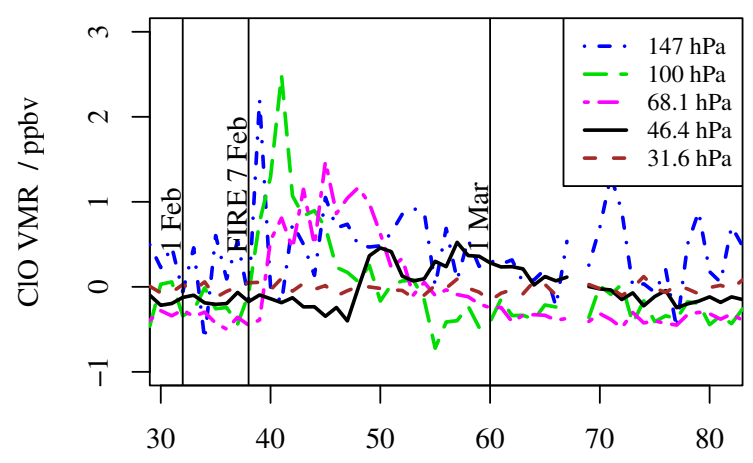

Time / Day of 2009

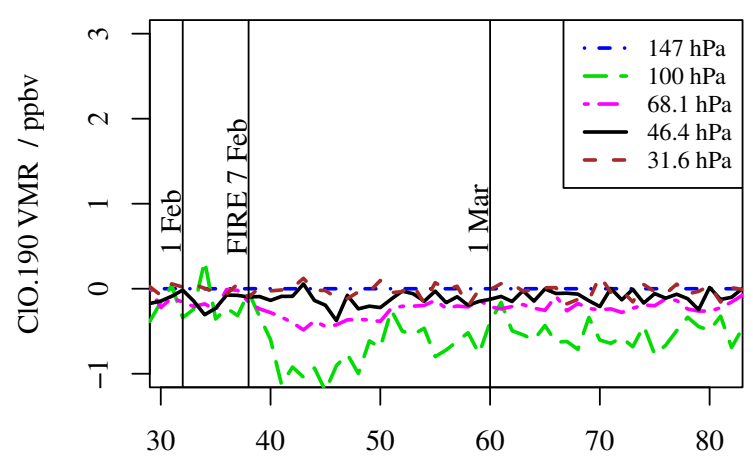

Time / Day of 2009

Fig. 6. Time series of the mixing ratio of $\mathrm{MLS} \mathrm{H}_{2} \mathrm{O}$ and $\mathrm{ClO}$ within the polluted airmass. Note the logarithmic axis used for $\mathrm{H}_{2} \mathrm{O}$.

Similar plots (not shown) were made for nitric acid $\left(\mathrm{HNO}_{3}\right)$, sulphur dioxide $\left(\mathrm{SO}_{2}\right)$, hydrogen chloride $(\mathrm{HCl})$ and ozone $\left(\mathrm{O}_{3}\right)$, none of which showed any obvious difference between the polluted period and the periods before and after.

$\mathrm{HCN}$ and $\mathrm{CH}_{3} \mathrm{CN}$ both have biomass burning as their only significant source in the atmosphere (Singh et al., 2003; Li et al., 2003). HCN, together with CO, has been previously observed from space to have elevated values in regions affected by biomass burning (Rinsland et al., 2005, 2007). The MLS HCN product is not recommended for general use in the $100 \mathrm{hPa}-10 \mathrm{hPa}$ range as it has large biases. It can, however, be used to qualitatively indicate large changes in the $\mathrm{HCN}$ mixing ratio. Retrieval of $\mathrm{HCN}$ is not attempted at pressures greater than $100 \mathrm{hPa}$. At the levels where it is retrieved, $\mathrm{HCN}$ shows enhancements at similar times and altitudes to those shown by $\mathrm{CO}$.

MLS is sensitive to $\mathrm{CH}_{3} \mathrm{CN}$ in two of its radiometers: those at $190 \mathrm{GHz}$ and $640 \mathrm{GHz}$. The retrieval software produces two separate $\mathrm{CH}_{3} \mathrm{CN}$ products but the $190 \mathrm{GHz}$ product is not of usable quality, so we show only the $640 \mathrm{GHz}$ product in Fig. 5. As with HCN, this shows a significant increase at similar times and altitudes to those shown by $\mathrm{CO}$.

Water vapour (Fig. 6) is produced by the fire itself but is also transported vertically by the strong convective events that are often triggered by fires. The plume appears to be considerably wetter than the surrounding air at $100 \mathrm{hPa}$ and $147 \mathrm{hPa}$, but the enhancement at $68 \mathrm{hPa}$ is small. In contrast to $\mathrm{CO}, \mathrm{HCN}$ and $\mathrm{CH}_{3} \mathrm{CN}$, no enhancement can be discerned at $46 \mathrm{hPa}$.

Chlorine monoxide $(\mathrm{ClO})$ is not normally thought of as a product of biomass burning; Andreae and Merlet (2001) give an extensive list on which it does not feature. As with $\mathrm{CH}_{3} \mathrm{CN}$, MLS measures $\mathrm{ClO}$ in both the $640 \mathrm{GHz}$ and $190 \mathrm{GHz}$ radiometers. Unlike $\mathrm{CH}_{3} \mathrm{CN}$, both $\mathrm{ClO}$ products are considered to be useful and are shown in Fig. 6. The $640 \mathrm{GHz}$ product is of higher quality (Santee et al., 2008) and is the standard product recommended for general use. The $640 \mathrm{GHz}$ product shows a substantial enhancement in the polluted airmass, but the $190 \mathrm{GHz}$ product shows no enhancement at all. (At $100 \mathrm{hPa}$ it actually shows a decrease from zero to $-1 \mathrm{ppbv}$; this is clearly a systematic error which becomes rapidly less serious with increasing height.) These results imply that there are unusual amounts of some molecule in the plume which is not $\mathrm{ClO}$ and which has spectral lines in the $640 \mathrm{GHz} \mathrm{ClO}$ band, but not in the $190 \mathrm{GHz} \mathrm{ClO}$ band. It is suggested by Santee et al. (2008) that the most likely candidate molecules are methyl chloride (chloromethane: $\mathrm{CH}_{3} \mathrm{Cl}$ ) and methanol $\left(\mathrm{CH}_{3} \mathrm{OH}\right)$. We investigate these possibilities by examining the measured radiances.

\subsubsection{Radiances}

We examined the radiances in the plume by choosing a day (14 February) on which the measurements with enhanced CO are located in a particularly small region: $30^{\circ}-35^{\circ} \mathrm{S}, 160^{\circ}$ $180^{\circ} \mathrm{W}$. We averaged the radiances from limb scans which lie within that region. As the tangent altitudes at which the radiances are reported are slightly different for each limb scan, we interpolate the radiances to a fixed vertical grid with a $1 \mathrm{~km}$ spacing before averaging. We then subtracted averaged radiances for the same latitudes and all other longitudes from this mean. The spectral features which show up should therefore be due to the pollution and not to latitudinal gradients. We show the results for the $190 \mathrm{GHz}$ radiometer in Fig. 7 and for the $640 \mathrm{GHz}$ radiometer in Fig. 8 . 

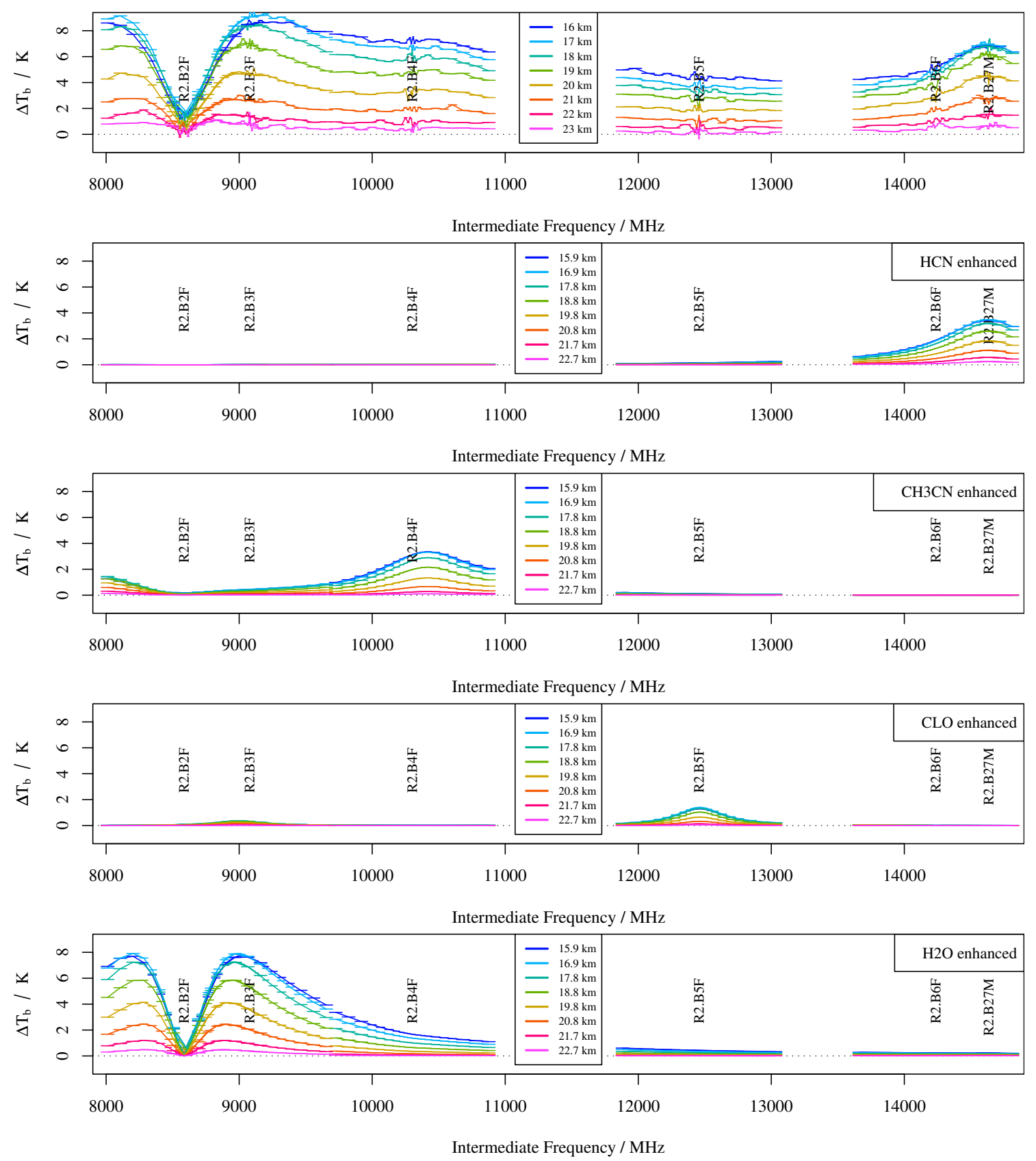

Fig. 7. Spectra from the $190 \mathrm{GHz}$ radiometer (R2) of MLS. The top panel is the measured difference between spectra in the plume and out of it. The other four panels show the difference between a default calculated spectrum and ones for which $\mathrm{HCN}, \mathrm{CH}_{3} \mathrm{CN}, \mathrm{ClO}$ and $\mathrm{H}_{2} \mathrm{O}$ are enhanced by roughly the amount observed in the retrieved profiles. If the top panel shows features similar to those in one of the other panels, this implies that the species which is enhanced in the calculation for the lower panel was also enhanced in the plume region. The vertical labels (e.g. R2.B5F) mark the centres of the individual filterbanks or "bands" which analyse the signal from this radiometer. Intermediate frequency is the difference between the frequency entering the instrument and the local oscillator frequency, which is $191.9 \mathrm{GHz}$ for R2; see Waters et al. (2006) for details.

As an aid to interpretation we also show in Figs. 7 and 8 calculated spectral differences for selected chemical species. These were produced by using a radiative transfer model to calculate the radiances which MLS would observe for a typical atmosphere, and then for the same atmosphere with the mixing ratio of a single species enhanced at the $100 \mathrm{hPa}$ and
$68 \mathrm{hPa}$ levels. If the measured radiance differences in the top panel show features similar to the calculated differences in one of the other panels, this implies that the species which is enhanced in the calculation for the lower panel was also enhanced in the plume region. 

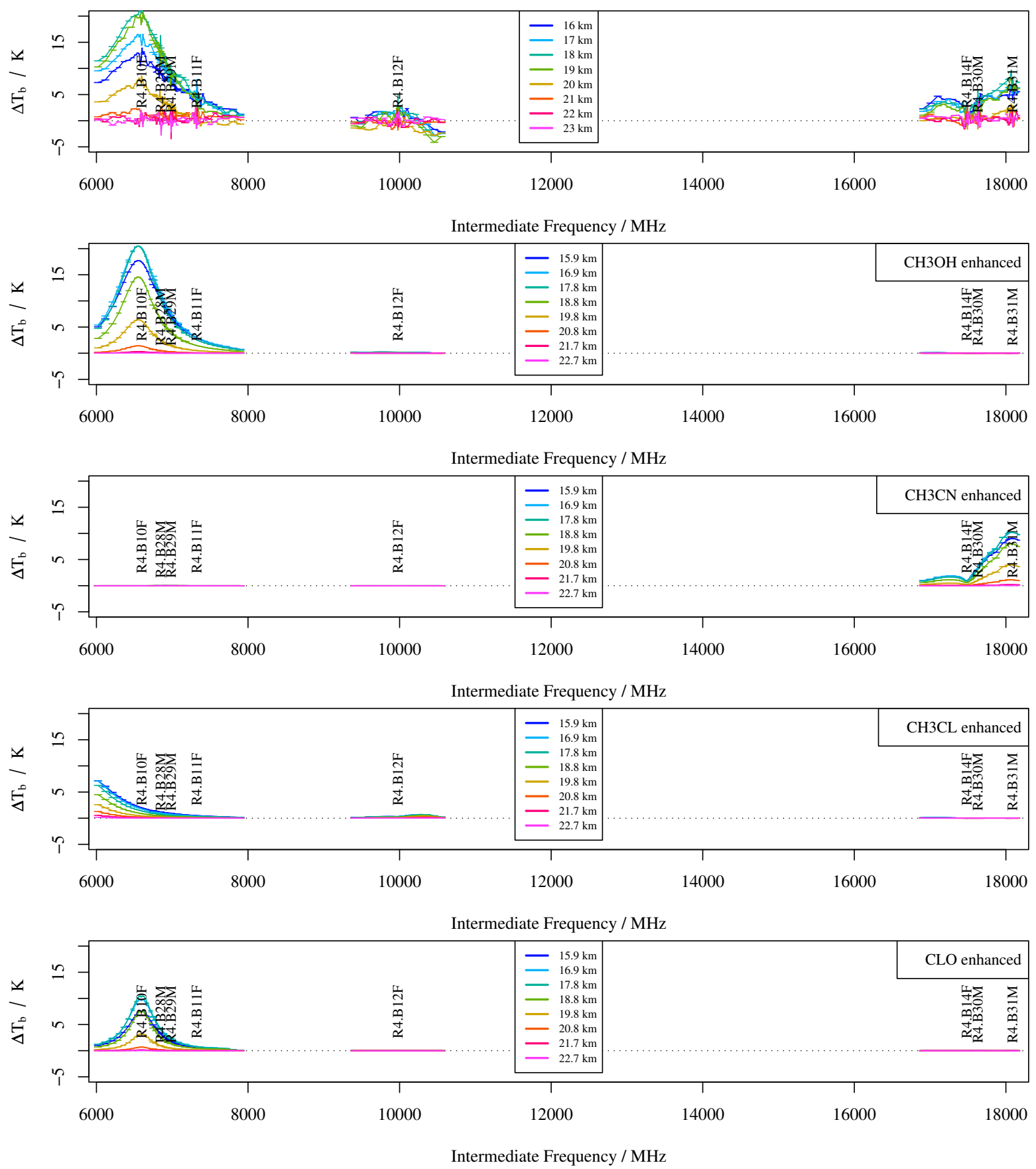

Fig. 8. Spectra from the $640 \mathrm{GHz}$ radiometer (R4) of MLS, plotted in the same manner as in Fig. 7. The top panel is the measured difference between spectra in the plume and out of it. The other four panels show the difference between a default calculated spectrum and ones for which $\mathrm{CH}_{3} \mathrm{OH}, \mathrm{CH}_{3} \mathrm{CN}, \mathrm{CH}_{3} \mathrm{Cl}$ and $\mathrm{ClO}$ are enhanced by roughly the amount observed in the retrieved profiles.

The $190 \mathrm{GHz}$ radiances from the plume are clearly enhanced in bands 6 and 27 due to HCN and in bands 2, 3 and 4 due to water vapour. (The centre of band 2 is less affected because water vapour at higher altitudes renders the atmosphere opaque at these frequencies. Radiation emitted in the lower stratosphere is re-absorbed and does not reach the instrument.) The enhancement in band 4 due to $\mathrm{CH}_{3} \mathrm{CN}$ is less clear against the enhancement from water vapour. The whole radiometer appears to also be affected by a spectrally flat enhancement; this may be due to a variety of effects which are not adequately handled by the radiative transfer model. There is no clear enhancement in the centre of band 5 of the instrument; this explains why the $\mathrm{ClO}$ retrieved from this band also shows no enhancement in the plume. 

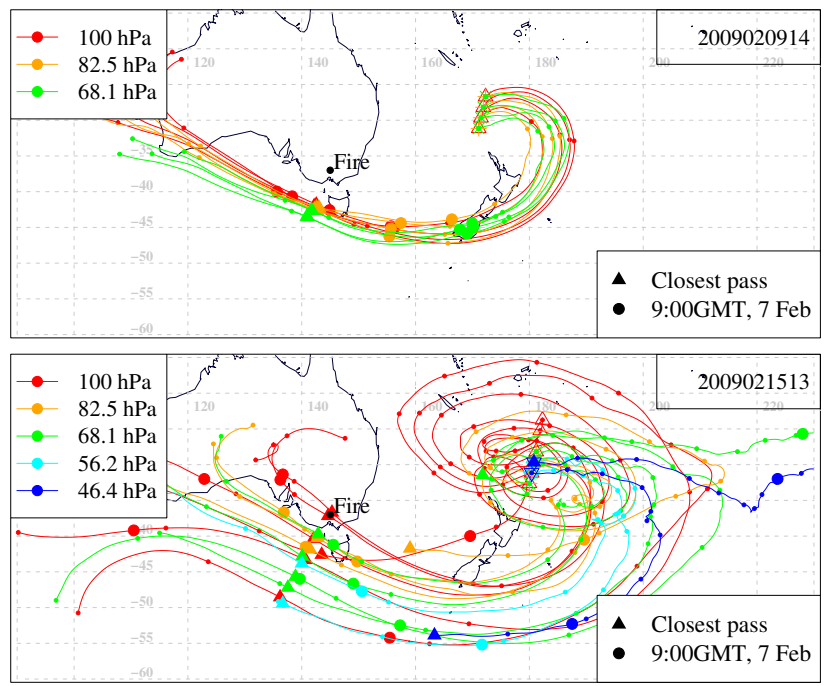

Fig. 9. Examples of back trajectories run from MLS measurement locations with elevated $\mathrm{CO}$ levels. The measurements in the top panel were made within 30 minutes of 14:00 UTC on 9 February, while those in the bottom panel were made within 30 minutes of 13:00 UTC on 15 February. (Starting date and UTC hour is shown on each panel in the form YYYYMMDDHH.) The small dots on the trajectories are placed at 24-h intervals.

The top panel of Fig. 8 shows that the $640 \mathrm{GHz}$ radiances from the plume region are clearly enhanced in bands 14,30 and 31 ; comparison with the third panel suggests that this enhancement is consistent with an enhanced $\mathrm{CH}_{3} \mathrm{CN}$ mixing ratio. The radiances from the plume are also clearly enhanced in bands 10, 11, 28 and 29. The enhancement is strongest in the centre of band 10. Comparison with the lower four panels of Fig. 8 suggests that this enhancement would not be consistent with enhancement of $\mathrm{CH}_{3} \mathrm{Cl}$ alone, but would be consistent with an enhancement of either methanol or $\mathrm{ClO}$. However, we know from the $190 \mathrm{GHz}$ radiances that the enhancement in $\mathrm{ClO}$ is negligible, leaving methanol as the most likely candidate. Note that some $\mathrm{CH}_{3} \mathrm{Cl}$ may also be present in the plume; it is difficult to be certain about this, but the asymmetric shape of the spectral peak is suggestive. The results shown in Figs. 7 and 8 imply that it should be possible to add $\mathrm{CH}_{3} \mathrm{OH}$ to the species routinely retrieved from the MLS measurements. This would require the use of data from both radiometers 2 and 4 in the same retrieval phase in order to separate the signals from $\mathrm{CH}_{3} \mathrm{OH}$ and $\mathrm{ClO}$. The calculated spectral radiance differences in the second panel of Fig. 8 were generated by increasing the methanol mixing ratio by $9.2 \mathrm{ppbv}$ at $68 \mathrm{hPa}$ and $3 \mathrm{ppbv}$ at $100 \mathrm{hPa}$. We next ask if an enhancement of that magnitude is likely, given the mixing ratio increase of $\mathrm{CO}$. On 14 February, the $\mathrm{CO}$ values in the plume were about $180 \mathrm{pbbv}$ and $220 \mathrm{ppbv}$ above the background value at $100 \mathrm{hPa}$ and $68 \mathrm{hPa}$, respectively. This implies a $\mathrm{CH}_{3} \mathrm{OH} / \mathrm{CO}$ emission ratio between 0.017 and 0.042 , in reasonable agreement with the values in the
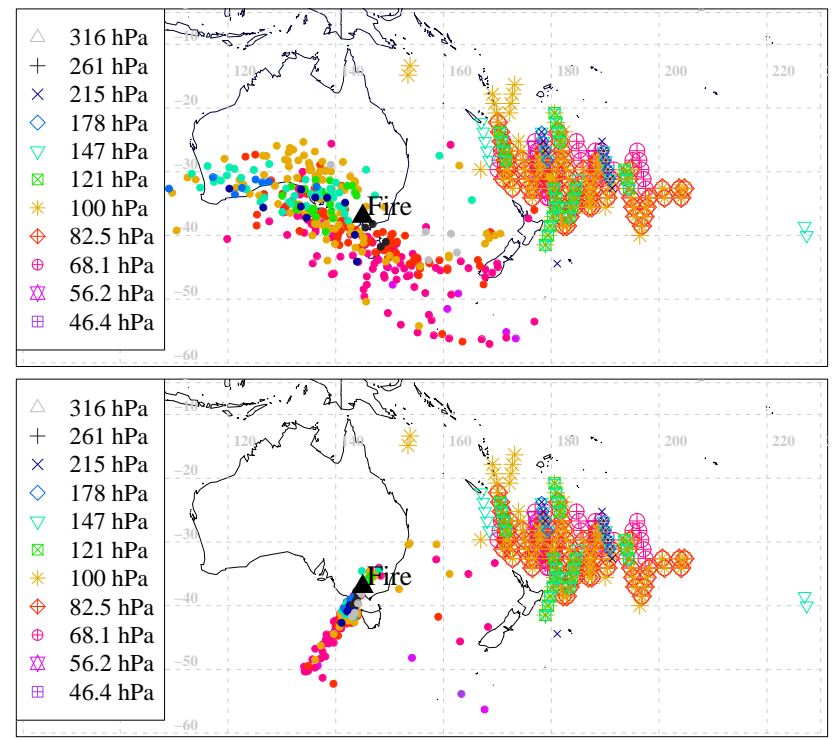

Fig. 10. Back trajectories run from MLS measurement locations with elevated $\mathrm{CO}$ levels for the ten days after the fire. The symbols in the legend show the locations of the MLS measurements. The filled circles show the trajectory location at 09:00 UTC on 7 February (upper map: examples are shown as filled circles in Fig. 9) and at the time of their closest pass to the fire region (lower map: examples are shown as triangles in Fig. 9).

literature. These published values range from 0.006 to 0.037 (Christian et al., 2003), with many reported values being close to 0.018 (Paton-Walsh et al., 2008; Andreae and Merlet, 2001). An earlier measurement of both $\mathrm{CO}$ and $\mathrm{CH}_{3} \mathrm{OH}$ from space (Rinsland et al., 2007) gives an emission ratio of $0.0278 \pm 0.00456$. The agreement of the methanol emission ratios estimated from the MLS measurements of the Black Saturday plume with those in the literature supports our hypothesis that methanol is the main species responsible for the signal observed in the $640 \mathrm{Gz}$ radiometer of MLS.

\section{Attribution}

While it seems a reasonable working hypothesis that the polluted airmass observed by MLS is the result of the Black Saturday fires, the observations for the first 12 days of the event are clustered in a rather restricted region which is not located over Victoria, but to the north of New Zealand. In order to strengthen or refute the hypothesis, we ran back-trajectory calculations from the MLS observations. The trajectories were produced using the online trajectory service of the British Atmospheric Data Centre (BADC) (http://badc.nerc. ac.uk/community/trajectory) driven by winds from the operational analysis of the European Centre for Medium-Range Weather Forecasts (ECMWF). Trajectories were launched at the latitude, longitude and pressure of each of the MLS positions where the $\mathrm{CO}$ mixing ratio was identified as unusually 


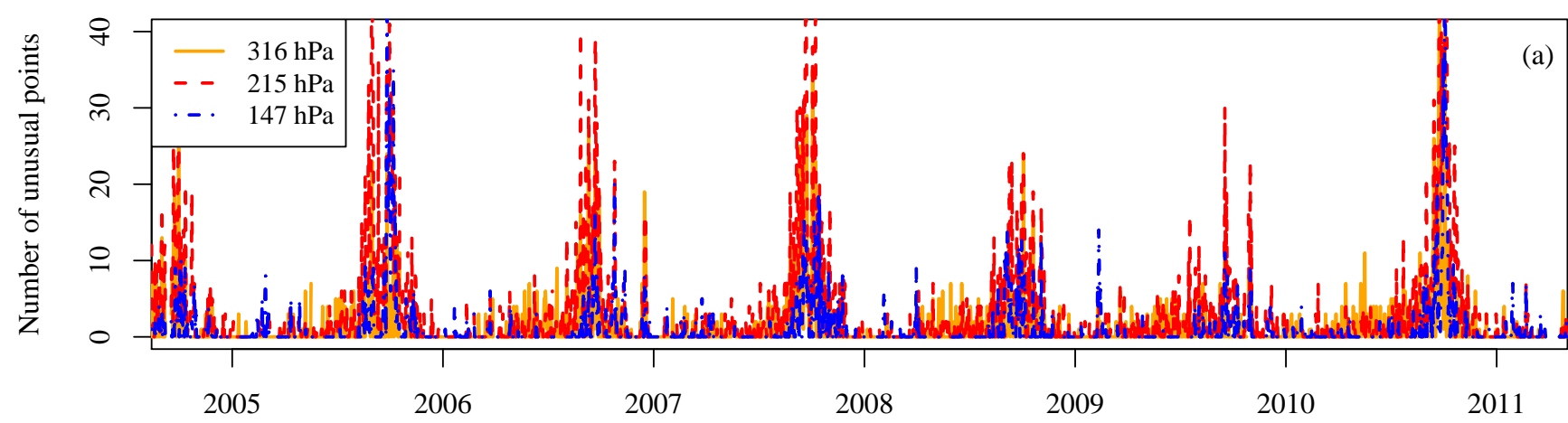

Time / years

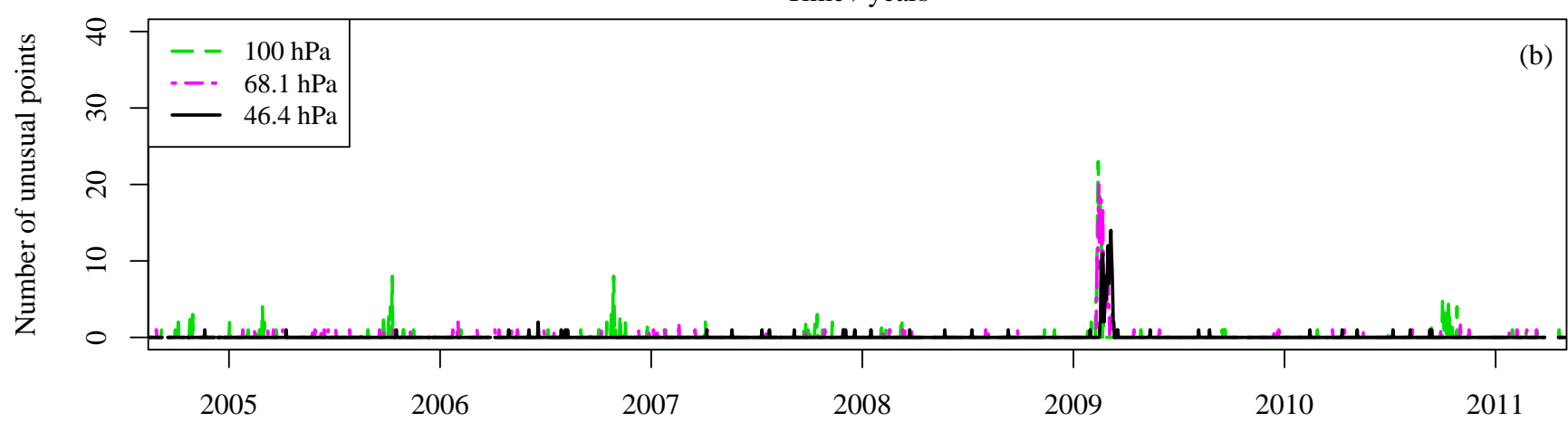

Time / years

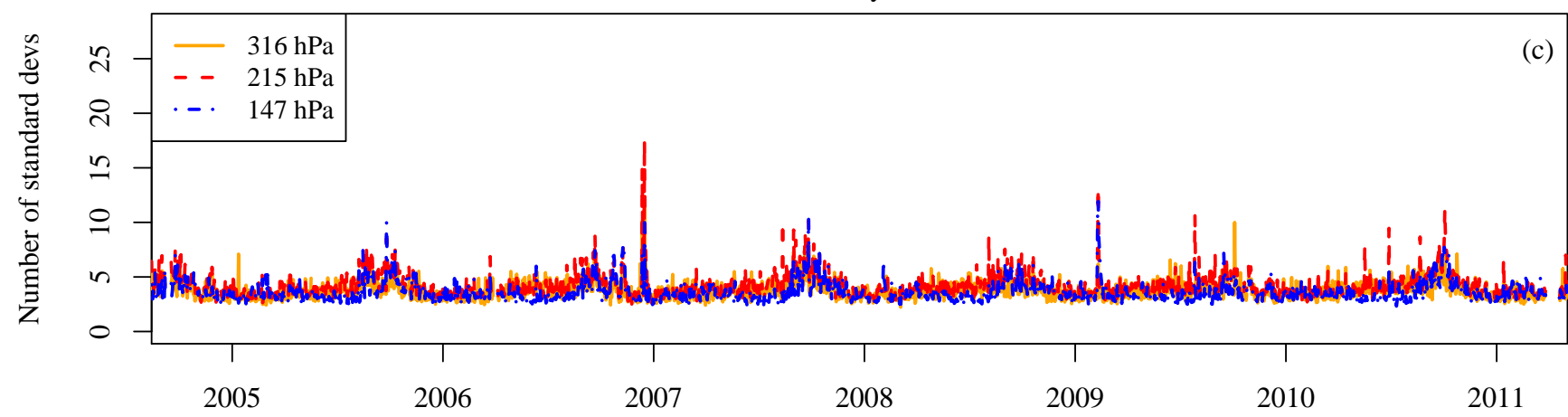

Time / years

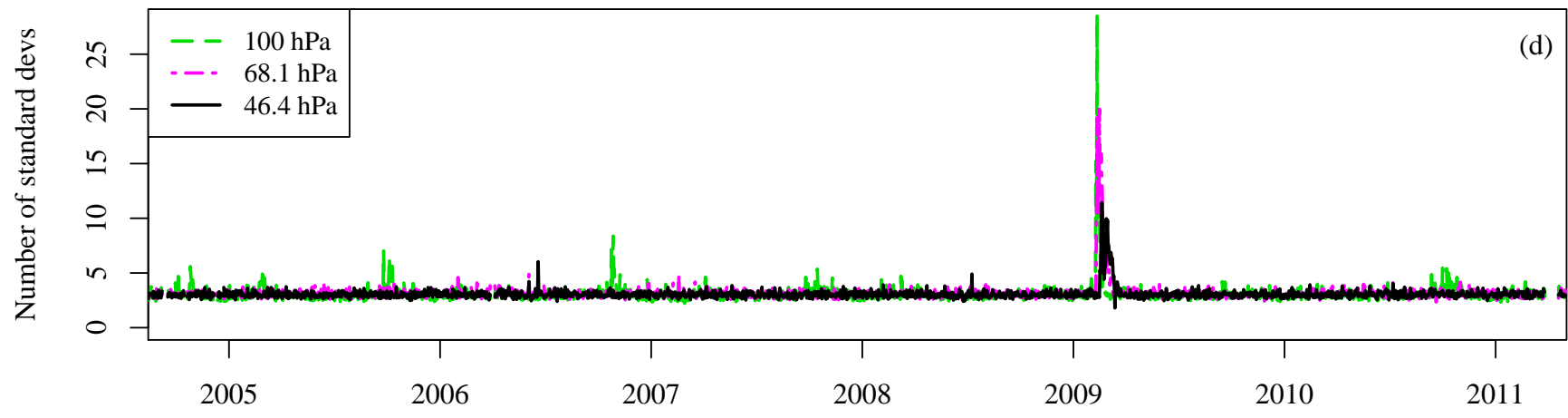

Time / years

Fig. 11. MLS CO data analysed as in Figs. 3 and 4 but for the entire mission. The troposphere and stratosphere levels are plotted on separate panels to improve clarity. Panels (a) and (b) are equivalent to Fig. 3; (c) and (d) are equivalent to Fig. 4 
high. If there were anomalous $\mathrm{CO}$ values at two adjacent pressure levels, an extra trajectory was launched at an intermediate pressure as well. Two examples are shown in Fig. 9.

Back trajectories like those in Fig. 9 were run for every hour in which an MLS observation of elevated $\mathrm{CO}$ was made during the ten days after the fires. The results are summarised in Fig. 10.

These trajectory calculations show that most of the polluted air parcels moved past southeastern Australia, travelling in an east-southeastwards direction, on the day of the fire. They reached New Zealand within a day and spent at least the next eight days executing anti-cyclonic motion in the region to the north of New Zealand. The process which injected the pollution into the stratosphere occurs on far too small a spatial scale to be captured by the trajectory calculations. However, the clustering of the closest passes to the south of the coast suggests that processes in the troposphere transported the pollutants south and west from the fire during the course of the injection process.

\section{The wider context}

In order to gain some understanding as to how unusual the Black Saturday event was for the lower stratosphere, we repeat the analysis shown in Figs. 3 and 4 for the entire MLS mission to date. The results are shown in Fig. 11.

We consider first the nominally upper-tropospheric levels $(316 \mathrm{hPa}, 215 \mathrm{hPa}$ and $147 \mathrm{hPa})$ shown in panels a and c. Viewed in terms of number of MLS locations affected per day (panel a), the Black Saturday event does not look unusual at a first glance. The most conspicuous feature of the time series is the annual biomass-burning season in South America and southern Africa, which occurs between July and November. The Black Saturday event occurred in February, and is more conspicuous when viewed in terms of how unusual the affected points are (panel c). Even then, it is of a similar magnitude to the event in late 2006. This event was observed between 12 and 17 December, initially to the East of New Zealand and moving towards South America. It seems plausible that it is connected with the Great Divide fires which burned throughout December 2006 and January 2007 in Victoria and New South Wales, Australia. The Great Divide fires were particularly intense in 9-11 December 2006, shortly before the peak seen in Fig. 11.

In the nominally stratospheric levels $(100 \mathrm{hPa}, 68.1 \mathrm{hPa}$ and $46.4 \mathrm{hPa}$, shown in panels $\mathrm{b}$ and d) the Black Saturday event is clearly unlike anything else that occurred during the MLS mission in the latitude range analysed, both in terms of the number of profiles affected and how different those profiles are from the usual state of the atmosphere. The only other events which stand out clearly from the background affect only the $100 \mathrm{hPa}$ level and are related to the annual biomass burning season seen in panels a and c. This feature is more clearly visible in 2005, 2006 and 2010; these are all years in which the biomass burning season appears vigorous in the upper-troposphere levels.

We carried out similar calculations to those shown in Fig. 11 for the other latitude regions of the Earth; again, we found no events in any way similar to the Black Saturday event.

The plume from the Black Saturday event has been observed by instruments other than MLS, including CALIPSO (Cloud-Aerosol Lidar and Infrared Pathfinder Satellite Observation, Winker et al., 2010), Odin-OSIRIS (Optical Spectrograph and InfraRed Imaging System, Siddaway and Petelina, 2011) and MIPAS (Michelson Interferometer for Passive Atmospheric Sounding) on Envisat (Sembhi et al., 2011). The position and motion of the plume observed by these instruments is in agreement with that observed by MLS.

\section{Conclusions}

In February/March 2009 MLS observed an unusual airmass in the lower stratosphere containing high concentrations of several biomass-burning products. Biomass-burning products directly observed by MLS in this airmass are $\mathrm{CO}, \mathrm{HCN}$, $\mathrm{CH}_{3} \mathrm{CN}, \mathrm{CH}_{3} \mathrm{OH}$ and possibly $\mathrm{CH}_{3} \mathrm{Cl}$. The $\mathrm{ClO}$ mixing ratios retrieved from the $640 \mathrm{GHz}$ MLS data imply that the airmass has enhanced $\mathrm{ClO}$ mixing ratios. This is, however, almost certainly due to $\mathrm{CH}_{3} \mathrm{OH}$, which has a similar spectral signature to $\mathrm{ClO}$ in the spectral region covered by MLS band 10. Trajectory calculations link this polluted airmass to the large bush fires which occurred in the state of Victoria, Australia on 7 February 2009. There is no other event of the same type and magnitude in the Aura MLS dataset.

Acknowledgements. Work at the Jet Propulsion Laboratory, California Institute of Technology, was carried out under a contract with the National Aeronautics and Space Administration. HCP thanks the University of Edinburgh for granting the sabbatical time during which this paper was written. Thanks are also due to Svetlana Petelina, Harjinder Sembhi, Mike Fromm and an anonymous referee for various helpful suggestions.

Edited by: W. Lahoz

\section{References}

Andreae, M. O. and Merlet, P.: Emission of trace gases and aerosols from biomass burning, Global Biogeochem. Cy., 15, 955-966, 2001.

Christian, T. J., Kleiss, B., Yokelson, R. Y., Holzinger, R., Crutzen, P. J., Hao, W. M., Saharjo, B. H., and Ward, D. E.: Comprehensive laboratory neasurements of biomass-burning emissions: 1. Emissions from Indonesian, African and other fuels, J. Geophys. Res., 108, 4719-4731, doi:10.1029/2003JD003704, 2003.

Coheur, P.-F., Herbin, H., Clerbaux, C., Hurtmans, D., Wespes, C., Carleer, M., Turquety, S., Rinsland, C. P., Remedios, J., Hauglustaine, D., Boone, C. D., and Bernath, P. F.: ACE-FTS observation 
of a young biomass burning plume: first reported measurements of $\mathrm{C}_{2} \mathrm{H}_{4}, \mathrm{C}_{3} \mathrm{H}_{6} \mathrm{O}, \mathrm{H}_{2} \mathrm{CO}$ and PAN by infrared occultation from space, Atmos. Chem. Phys., 7, 5437-5446, doi:10.5194/acp-75437-2007, 2007.

Coheur, P.-F., Clarisse, L., Turquety, S., Hurtmans, D., and Clerbaux, C.: IASI measurements of reactive trace species in biomass burning plumes, Atmos. Chem. Phys., 9, 5655-5667, doi:10.5194/acp-9-5655-2009, 2009.

Fromm, M. D. and Servranckx, R.: Transport of forest fire smoke above the tropopause by supercell convection, Geophys. Res. Lett., 30, 1542, doi:10.1029/2002GL016820, 2003.

Fromm, M. D., Lindsey, D. T., Servranckx, R., Yue, G., Trickl, T., Sica, R., Doucet, P., and Godin-Beekmann, S.: The Untold Story of Pyrocumulonimbus, Bull. Am. Meteorol. Soc., 91, 1193-1209, doi:10.1175/2010BAMS3004.1, 2010.

Li, Q., Jacob, D. J., Yantosca, R. M., Heald, C. L., Singh, H. B., Koike, M., Zhao, Y., Sachse, G. W., and Streets, D. G.: A global three-dimensional model analysis of the atmospheric budgets of $\mathrm{HCN}$ and $\mathrm{CH}_{3} \mathrm{CN}$ : Constraints from aircraft and ground measurements, J. Geophys. Res, 108, 8827, doi:10.1029/2002JD003075, 2003.

Livesey, N. J., Fromm, M. D., Waters, J. W., Manney, G. L., Santee, M. L., and Read., W. G.: Enhancements in lower stratospheric $\mathrm{CH}_{3} \mathrm{CN}$ observed by UARS MLS following boreal forest fires., J. Geophys. Res., 109, D06308, doi:10.1029/2003JD004055, 2004.

Livesey, N. J., Snyder, W. V., Read, W. G., and Wagner, P. A.: Retrieval algorithms for the EOS Microwave Limb Sounder (MLS) instrument, IEEE Trans. Geosci. Remote Sens., 44, 1144-1155, 2006.

Livesey, N. J., Read, W. G., Lambert, A., Cofield, R. E., Cuddy, D. T., Froidevaux, L., Fuller, R. A., Jarnot, R. F., Jiang, J. H., Jiang, Y. B., Knosp, B. W., Kovalenko, L. J., Pickett, H. M., Pumphrey, H. C., Santee, M. L., Schwartz, M. J., Stek, P. C., Wagner, P. A., Waters, J. W., and Wu., D. L.: Earth Observing System (EOS) Aura Microwave Limb Sounder (MLS) Version 2.2 Level 2 data quality and description document., Tech. Rep. JPL D-33509, NASA Jet Propulsion Laboratory California Institute of Technology, Pasadena, California, 91109-8099, http://mls.jpl.nasa.gov (last access: 30 June 2011), 2007.

Livesey, N. J., Filipiak, M., Froidevaux, L., Read, W., Lambert, A., Santee, M., Jiang, J., Pumphrey, H., Waters, J., Cofield, R., Cuddy, D., Daffer, W., Drouin, B., Fuller, R., Jarnot, R., Jiang, Y., Knosp, B., Li, Q., Perun, V., Schwartz, M., Snyder, W., Stek, P., Thurstans, R., Wagner, P., Avery, M., Browell, E., Cammas, J.-P., Christensen, L., Diskin, G., Gao, R.S., Jost, H.-J., Loewenstein, M., Lopez, J., Nedelec, P., Osterman, G., Sachse, G., and Webster, C.: Validation of Aura Microwave Limb Sounder $\mathrm{O}_{3}$ and $\mathrm{CO}$ observations in the upper troposphere and lower stratosphere, J. Geophys. Res, 113, D15S02, doi:10.1029/2007JD008805, 2008.

Paton-Walsh, C., Wilson, S. R., Jones, N. B., and Griffith, D. W. T.: Measurement of Methanol Emissions from Australian Wildfires by Ground-based Solar Fourier Transform Spectroscopy, Geophys. Res. Lett., 35, L01880, doi:10.1029/2007GL032951, 2008.

Pumphrey, H. C., Jimenez, C. J., and Waters, J. W.: Measurement of HCN in the middle atmosphere by EOS MLS, Geophys. Res. Lett., 33, L08804, doi:10.1029/2005GL025656, 2006.

Pumphrey, H. C., Filipiak, M. J., Livesey, N. J., Schwartz, M. J., Boone, C., Walker, K. A., Bernath, P., Ricaud, P., Barret, B.,
Clerbaux, C., Jarnot, R. F., Kovalenko, L. J., Manney, G. L., and Waters, J. W.: Validation of middle-atmosphere carbon monoxide retrievals from MLS on Aura, J. Geophys. Res., 112, D24S38, doi:10.1029/2007JD008723, 2007.

Pumphrey, H. C., Boone, C., Walker, K. A., Bernath, P., and Livesey, N. J.: Tropical tape recorder observed in HCN, Geophys. Res. Lett, 35, L05801, doi:10.1029/2007GL032137, 2008.

Rinsland, C. P., Boone, G. D. C. D., Bernath, P. F., and Chiou, L.: Atmospheric Chemistry Experiment (ACE) measurements of elevated Southern Hemisphere upper tropospheric CO, $\mathrm{C}_{2} \mathrm{H} 6$, $\mathrm{HCN}$, and $\mathrm{C}_{2} \mathrm{H}_{2}$ mixing ratios from biomass burning emissions and long-range transport, Geophys. Res. Lett., 32, L20803, doi:10.1029/2005GL024214, 2005.

Rinsland, C. P., Dufour, G., Boone, C. D., Bernath, P. F., Chiou, L., Pierre-Fran c. C., Turquety, S., and Clerbaux, C.: Satellite boreal measurements over Alaska and Canada during JuneJuly 2004: Simultaneous measurements of upper tropospheric $\mathrm{CO}, \mathrm{C}_{2} \mathrm{H}_{6}, \mathrm{HCN}, \mathrm{CH}_{3} \mathrm{Cl}, \mathrm{CH}_{4}, \mathrm{C}_{2} \mathrm{H}_{2}, \mathrm{CH}_{3} \mathrm{OH}, \mathrm{HCOOH}$, OCS, and $\mathrm{SF}_{6}$ mixing ratios, Global Biogeochem. Cy., 21, GB3008, doi:10.1029/2006GB002795, 2007.

Santee, M. L., Lambert, A., Read, W. G., Livesey, N. J., Manney, G. L., Cofield, R. E., Cuddy, D. T., Daffer, W. H., Drouin, B. J., Froidevaux, L., Fuller, R. A., Jarnot, R. F., Knosp, B. W., Perun, V. S., Snyder, W. V., Stek, P. C., Thurstans, R. P., Wagner, P. A., Waters, J. W., Connor, B., Urban, J., Murtagh, D., Ricaud, P., Barret, B., Kleinbohl, A., Kuttippurath, J., Kullmann, H., von Hobe, M., Toon, G. C., , and Stachnik, R. A.: Validation of the Aura Microwave Limb Sounder ClO measurements, J. Geophys. Res., 113, D15S22, doi:10.1029/2007JD008762, 2008.

Schneider, J., Bürger, V., and Arnold, F.: Methyl cyanide and hydrogen cyanide measurements in the lower stratosphere: Implications for methyl cyanide sources and sinks., J. Geophys. Res., 102, 25501-25506, 1997.

Schoeberl, M. R., Douglass, A. R., Hilsenrath, E., Bhartia, P. K., Barnett, J., Beer, R., Waters, J., Gunson, M., Froidevaux, L., Gille, J., Levelt, P. F., and DeCola, P.: Overview of the EOS Aura Mission, IEEE Trans. Geosci. Remote Sens., 44, 10661074, 2006.

Sembhi, H., Remedios, J., Spang, R., Trent, T., and Moore, D.: Detecting Global Cloud and Aerosol Particle occurrence with Limb Emission Measurements from the MIPAS-E, Atmos. Meas. Tech. Discuss., in preparation, 2011.

Siddaway, J. M. and Petelina, S. V.: Transport and evolution of the 2009 Australian Black Saturday bushfire smoke in the lower stratosphere observed by OSIRIS on Odin, J. Geophys. Res., 116, D06203, doi:10.1029/2010JD015162, 2011.

Singh, H. B., Salas, L., Herlth, D., Kolyer, R., Czech, E., Viezee, W., Li, Q., Jacob, D. J., Blake, D., Sachse, G., Harward, C. N., Fuelberg, H., Kiley, C. M., and Kondo, Y. Z. Y.: In situ measurements of $\mathrm{HCN}$ and $\mathrm{CH}_{3} \mathrm{CN}$ over the pacific ocean: Sources, sinks and budgets, J. Geophys. Res., 108, 8795, doi:10.1029/2002JD003006, 2003.

Teague, B., McLeod, D., and Pascoe, S.: 2009 Victorian Bushfires Royal Comission - Final Report, Tech. rep., 2009 Victorian Bushfires Royal Comission, http://www.royalcommission. vic.gov.au, 2010.

Turquety, S., Hurtmans, D., Hadji-Lazaro, J., Coheur, P.-F., Clerbaux, C., Josset, D., and Tsamalis, C.: Tracking the emission and transport of pollution from wildfires using the IASI CO re- 
trievals: analysis of the summer 2007 Greek fires, Atmos. Chem. Phys., 9, 4897-4913, doi:10.5194/acp-9-4897-2009, 2009.

Waters, J. W., Froidevaux, L., Harwood, R., Jarnot, R., Pickett, H., Read, W., Siegel, P., Cofield, R., Filipiak, M., Flower, D., Holden, J., Lau, G., Livesey, N., Manney, G., Pumphrey, H., Santee, M., Wu, D., Cuddy, D., Lay, R., Loo, M., Perun, V., Schwartz, M., Stek, P., Thurstans, R., Boyles, M., Chandra, S., Chavez, M., Chen, G.-S., Chudasama, B., Dodge, R., Fuller, R., Girard, M., Jiang, J., Jiang, Y., Knosp, B., LaBelle, R., Lam, J., Lee, K., Miller, D., Oswald, J., Patel, N., Pukala, D., Quintero, O., Scaff, D., Snyder, W., Tope, M., Wagner, P., and Walch, M.: The Earth Observing System Microwave Limb Sounder (EOS MLS) on the Aura satellite, IEEE Trans. Geosci. Remote Sens., 44, 1106-1121, 2006.
Winker, D. M., Pelon, J., Jr., J. A. C., Ackerman, S. A., Charlson, R. J., Colarco, P. R., Flamant, P., Fu, Q., Hoff, R. M., Kittaka, C., Kubar, T. L., Treut, H. L., McCormick, M. P., Mégie, G., Poole, L., Powell, K., Trepte, C., Vaughan, M. A., and Wielicki, B. A.: The CALIPSO Mission: A Global 3D View of Aerosols and Clouds, Bull. Am. Meteorol. Soc., 91, 1211-1229, doi:10.1175/2010BAMS3009.1, 2010. 